\title{
Literature as cultural ecology: a cultural ecological study on Emerson and Whitman
}

\section{Melis Mülazımoğlu'}

1 Assist. Prof. Dr., Ege University, Faculty of Literature, Department Of American Culture And Literature, Bornova, Izmir, TURKEY, E-mail: meliserkal@yahoo.com

\begin{abstract}
This article is intended to find out how a cultural ecological reading is possible for the selected poems of Emerson and Whitman who are considered as the leading figures of the nineteenth century American Renaissance, the artistic spirit which has flourished between the 1830s-1860s in the wake of the Romantic movement. Transcendentalism in America, as a projection of English Romanticism and Christian Unitarianism interprets the organic interaction in-between man, nature and God. Giving the earliest examples of Transcendentalist nature-writing, Emerson and Whitman are open for a cultural-ecological reading because cultural ecology as a new direction in ecocriticism, brings together ecology and aesthetics, nature and man, environment and literature, language and culture in other words human and non-human universes. As an inter-disciplinary theory developing in a dynamic way, cultural ecology, according to Zapf, "can be described as the interrelation of three major discursive functions such as the 'culture-critical metadiscourse,' 'an imaginative counter-discourse,' and a 'reintegrative inter-discourse'" (2016: 96). In the first model, the artistic work is analyzed to reveal the workings of an oppressive ideological structure and dogmatic values of the society whereas the second one points out the representations of otherness and marginalization within a text and finally last one tries to exemplify the co-evolution of both models in searching for the "transformative role of literature" within "eco-semiotic" discourse. In that sense, this article intends to find out how the poetic examples of Emerson and Whitman fit into the triadic model of cultural ecology. The argument proceeds through the illustration of Zapf's triadic model in Emerson's "Hamatreya," and Whitman's "The Splendid, Silent Sun."
\end{abstract}

Keywords: Cultural Ecology, Transcendentalism, Ecocriticism, Whitman, Emerson

Citation/Atıf: MÜLAZIMOĞLU, M. (2021). Literature as cultural ecology: a cultural ecological study on Emerson and Whitman. Journal of Awareness. 6(2), 95-104, DOI: https://doi.org/10.26809/joa.6.2.01 


\section{INTRODUCTION}

This article intends to find out how a cultural ecological reading is possible for the selected poems of Ralph Waldo Emerson (1803-1882) and Walt Whitman (1819-1892) who are considered as the leading figures of the nineteenth century American Renaissance, in which the artistic spirit has flourished between the 1830s-1860s in the wake of the Romantic Movement. As a projection of the English Romanticism and Christian Unitarianism; Transcendentalism in America thanks to R. W. Emerson's contributions in foregrounding the theoretical structure of the movement and Henry David Thoreau's endeavor to put them in practice, has flourished among New England intellectuals who have interpreted the interaction in-between man, nature and God by treating each unit equally, separately and as a whole. In the frame of Transcendentalist worldview, the existence of opposite poles in universe such as nature and culture, individual and society, male and female, human and non-human, inside and outside, spirit and mind, the East and West, etc. are observed to be complementary, holistic and one rather than dualistic and hierarchical; thus, transcendentalist literature which centers on the readjustment of a) nature in man, b) man in nature and c) god in man/ nature turns out to be a progressive, dynamic body of work, modified and expanded each time it is received by the audiences. It can be said for such kinds of texts and transcendentalist narratives are some of those "Song of Myself" being the best example by far- that "they represent a sustainable form of textuality, which, in the very indeterminacy and polysemic openness of aesthetic processes, provides a source of critical selfreflection and ever-renewable creative energy for ever new generations of readers"' (Rueckert, 1978: 110).

As for the emphasis on the individual, Transcendentalism has been other than solipsistic; its awareness for the Self can be explained in a cosmic frame that connects selfhood with "the ecology of the mind," which is defined by Gregory Bateson as "the fundamental unity of the human self and the broader system of ecological organization. Here the mind is evidently not considered as a subjective power, but rather an ecological function that mirrors the ineludible material interrelatedness between the self and the environment (qtd in Iovino and Oppermann, 2012: 76). Contrary to many critics who have viewed Transcendentalism as intensely egocentric, this article argues that it is anthropomorphic ${ }^{1}$-not to be confused

\footnotetext{
1 Anthropomorphism is attribution of human characteristics to non-humans, animals, divine beings, forces of nature whereas anthropocentrism means regarding human as the center of universe above all considerations, and this is a fatal fallacy in the context of ecocriticism and material ecology. "In-
}

with anthropocentric- as the transcendentalist self is embodied within an infinite network of experiences and perceptions formed through the interplay between the human and nonhuman agencies, agencies of matter and beyond:

In the context of material ecocriticism, the humanization of things, places, natural elements, nonhuman animals, is not necessarily the sign of an anthropocentric and hierarchical vision but can be a narrative expedient intended to stress the agentic power of matter and the horizontality of its elements. If conceived in this critical perspective, anthropomorphizing representations can reveal similarities and symmetries between the human and the nonhuman. (Iovino and Oppermann, 2012: 82)

In that sense, the transcendentalist self as much as the transcendentalist narrative is placed in a "choreography of becoming" (Coole and Frost qtd in Iovino and Oppermann, 2012: 79). Therefore, it is not only the ecology of text that matters but also the textuality of ecology that treats each separate unit as equal, organic and dynamic.

The intersection between Transcendentalist philosophy and cultural ecology appears at this moment as both platforms have been open to dynamic developing of dichotomies, polyphonic discourses and interconnectedness ${ }^{2}$ within/across texts as well as ecologies. Other than that, literature as cultural ecology borrowing from material ecocriticism and cultural ecology, develops a "specific theory and proposes a triadic functional model for describing the transformative role of imaginative texts within cultural systems and discourses" (Zapf, 2016: 7). In that sense, "literature is described as a transformative force of language and discourse, which combines civilizational critique with cultural self-renewal in ways that turn literary texts into forms of sustainable textuality" (Zapf, 2016: 7).

This study centers on the cultural ecological reading of Transcendentalist poems as poetry according to the famous ecocritic Rueckert is a stored energy, a living thing, energy pathway that sustains life:

Poems are green plants among us [...] help to create a self-perpetuating and evolving system. That is, they help to create creativity and community and when their

stead of stressing categorical divides, anthropomorphism potentially works against anthropocentrism" (Bennett qtd in Iovino and Oppermann 82).

2 As William Rueckert notes, poems can be studied as models for energy flow, community building, and ecosystems. Barry Commoner's first Law of Ecology - that everything is connected to everything else - applies to poems as well as to nature. The concept of the interactive field has been operative in nature, ecology and poetry long before it ever appeared in criticism (Rueckert, 1978: 110). 
energy is released and flows out into others, to again raise matter from lower to higher order [...]. As Barry Commoner points out, "the complex web in which all life is enmeshed, and man's place in it, are clearly-and beautifully described in the poems of Walt Whitman, in Melville's Moby Dick and everywhere in Emerson and Thoreau. (Rueckert, 1978: 111, 115)

Emerson's works have been influential upon younger generation of poets, especially on Whitman who, after listening to one of Emerson's speeches delivered in New York in 1842, has decided to become the poet Emerson is searching vehemently as the old mentor who used to comment sadly, "I look in vain for the poet whom I describe" (Shucard,1988: 150). Taking after the Emersonian fashion, young Whitman soon has realized Emersonian Transcendentalism in his works, best reflected in his Leaves of Grass (1855). Emerson's attempt to display "the fusion between substance and spirit, the world of the physical experience and the Over-Soul" (Shucard, 1988: 133) articulated in a poetic form commonly known as the "speech-based verse" that has been a remarkable poetic model for Whitman. What is more, Whitman has gone beyond Emerson's practices as he develops an urban consciousness and a strong tie with Jeffersonian democracy all of which help him foster his poetics free of cultural, sexual, racial, religious restrictions. The Emersonian legacy is best visible in Whitman's Preface to Leaves of Grass, written as an introduction to his poetry that summarizes Emerson's conception of the ideal poet and function of poetry.

As for the exemplification of literature as cultural ecology, this article follows a discussion of Emerson's "Hamatreya," and Whitman's "The Splendid, Silent Sun." Regarding Zapf's triadic model that functions on a "culture-critical meta-discourse", "imaginative counter-discourse," and a "reintegrative interdiscourse" (Zapf, 2016: 96). The study begins with the introduction of Zapf's theory of literature as cultural ecology, which is followed by separate chapters on Emerson and Whitman who altogether help reestablish an "adaptation of human to nature, nature to human and co-evolution of both" (26).

\section{THEORETICAL BACKGROUND: LITERATURE AS CULTURAL ECOLOGY}

The German critic H. Zapf has formulated his theory of "literature as cultural ecology" in his book entitled Literature as Cultural Ecology: Sustainable Texts in 2000, borrowing from ecocriticism and cultural ecology 3 Speech-based poetry, formulated by Emerson popularized by Whitman, follows the unrhymed, long line structure contrary to metrical verse types (Shucard, 1988: 169). and mainly relying on the ideas of Gregory Bateson, Peter Finke, Wolfgang Iser, Adorno and Horkheimer, Schelling, Nietzsche, Bakhtin to name a few. According to Bateson's concept of the "ecology of mind," the mind is a "dehierarchized concept of a mutual dependency between the (human) organism and its (natural) environment, subject and object, culture and nature" (Zapf, 2016: 8). Moreover, Peter Finke's regarding of cultural ecology as a paradigm not only for the natural and human sciences, but for cultural studies as well (79) is further developed by Zapf's reading of Iser's method for literary anthropology and Pierce's semiotics together with Schelling's fusion of matter and mind, Bakhtin's polymorphic discourse and finally with Nietzsche's notions of the Apollonian and Dionysian forces. In this sense, according to Zapf, literature can itself be described as the symbolic medium of interconnectedness operating between nature and culture, human and non-human universes; thus, literary works can be examined as the dynamic interrelation of three major discursive functions as of a "culture-critical meta-discourse, an imaginative counter-discourse, and a reintegrative inter-discourse":

Literature in this sense is, on the one hand, a sensorium for what goes wrong in a society, for the biophobic, life-paralyzing implications of one-sided forms of consciousness and civilizational uniformity, and it is, on the other hand, a medium of constant cultural selfrenewal, in which neglected biophilic energies can find a symbolic space of expression and of reintegration into the larger ecology of cultural discourses. (Zapf, 2016: 91)

According to the first functionality of literature as culture-critical meta-discourse, the text acts like a regulator in demonstrating the weak points of a culture. The text is perceived to respond to the representation of hegemonic structure of dominant ideology in one society through the enforcement of oppression, subjection, repression, imprisonment, alienation, deterioration, conformism, etc in the body of a work. This way, the text prevails as a means to display the workings of dominant ideology enforced upon humans and non-humans. For instance, the representations of death-in-life situation and draught as a result of WWI in T.S. Eliot's "The Waste Land" or entrapment of the female as a result of restrictive gender roles and patriarchy in Charlotte Perkins Gilman's The Yellow Wallpaper might be taken into consideration for the first model of functionality.

The second model appears as a response to the first 
one in the form of counter-discourse which empowers the marginal, silenced, other in a text. Giving room to the marginalized voices, the second model emphasizes on change, energy, dynamism, subversion, challenge, contact, flux, etc. Therefore, the text is presented as a place to allow the free play of divergent entities so that the other side of ruling ideology will be unraveled. Self-expression of the female through the patterns of the wallpaper in Gilman's work along with the self-expression of thunder as "Datta, Dayadhvam, Damyata" in Eliot's poem prove to be examples for the second model of functionality.

The last model is the functionality of a reintegrative inter-discourse that works as a process in bringing conformist and non-conformist spheres or separate voices together to provide sustainability for literature. The reintegration in a text does not have to come into being always in terms of a peaceful co-operation or positive ending; the insanity of the female at the end of Gilman's short story as a gateway to freedom or the rain after thunder in T.S. Eliot's "The Waste Land" may be the sign for reintegrative inter-discourses in literature. As it is briefly explained above, Zapf's triadic functional model describes the transformative role of imaginative texts within cultural systems and discourses (Zapf, 2016:7).

As argued in Zapf's work, what values literature as cultural ecology is the diversity inherit in a text that is, the representation of opposing forces and the coexistence of the varied forms of human and non-human both and on a textual and socio-cultural level. In this way, the creative energies of texts can travel across periods and cultures and can be shared by a potentially global audience (Zapf, 2016:14). This represents a sustainable form of textuality, which, in the very indeterminacy and polysemic openness of aesthetic processes, provides a source of critical selfreflection and ever-renewable creative energy for new generations of readers (Rueckert qtd in Zapf, 2016: 14).

\section{R. W. EMERSON'S "HAMATREYA" (1847)}

Ralph Waldo Emerson (1803-1882), as the founding father of the philosophical movement, Transcendentalism has argued in his essay The Nature that a) words are signs of natural facts, b) particular natural facts are symbols of particular spiritual facts, c) nature is the symbol of spirit. (Emerson, 1844a: 20). With this argument, he claims divinity dwells in the physical world and human mind can participate in that reality. Moreover, he claims that on a symbolic level each emblem is a reflection of outside physicality, which is implanted in a higher world. For Emerson, nature is a book to read one's presence as much as the presence of the Universal, intertwined with the Transcendentalist readings of the Self and Other (Shucard, 1988: 130). The task of the poet, according to Emerson is to be the sayer, namer, more like a prophetic figure who can represent cosmic beauty through each diversity that makes it. As for the subject matter, all he has to consider lies in front of him, in the vastness of the nation, itself. Thus, to him, the ideal poet is the one who can reflect oneness and wholeness derived from the opposites in universe, reflected on paper not in meters but in a meter-making argument form. Owing to all unconventional points he has welcomed in poetic speech including form and content, Emerson has been interpreted as the founding father, the essential scholar behind Transcendentalism. As he asserts in his essay The Poet, "every word has once been a poem, every new relation is a new word" (R. W. Emerson, 1844b: np), Emerson underlines connectivity not only in between human and non-human universes but also in-between textuality and ecology. Therefore, the ideas of inter-relatedness and diversity, similarity and difference, connectivity and singularity (Zapf, 2016: 12) find a perfect place in Emerson's poetics, which might be titled as "eco-ecriture."

Emerson's poem “Hamatreya" (1847) takes its title after the Hindu god, Maitreya/Hamatreya. The poem is mainly about the individual quest of understanding nature through a critique of Westward expansion and nineteenth century Industrialism. The poem is divided into three sections and each section follows a different verse type such as blank verse, free-verse and stanzaic. The first section is told in blank-verse from the mouth of the persona who is a human being (in-stand for Emerson, himself) talking about the earliest settlers of Concord, including Emerson's ancestor, Bulkeley who like other landlords expressed pleasure, power and vanity in exploiting the natural resources and crops of the land like "hay, corn, roots, hemp, flax, apples, wool and wood/ [...] clay, lime, gravel, granite-ledge, / And misty lowland, where to go for peat" (Emerson, 1847: line 3, 20) "which rendered to their toil" (line 2). The subjection of the land is further explained in the next line where nature is regarded as "property" that "belongs" not only to the landlords, but also to their families, his sons, to younger generations who will see his grandparents' name enwritten on nature. In such a delicate portrayal of perfect obedience, the west wind sounds "sweet," the trees climb in "grace," the water is "pure" all of which render service to man's affirmation of the land like a "loyal dog" would obey his "master." It has been a god-blessing luxury for those "hot 
owners" who went abroad knowing that their land waited for their return as a wife awaited her man: "It is good when you have crossed the sea and back/ to find sit fast acres where you left them" (lines 23-24). Emerson now asks "where are these men? Asleep beneath their grounds" (line 11). As no one can stand against death, not even the founding fathers; farmers and foreigners are now walking on their (landlords') graves or ploughing the soil not knowing who lies beneath, nor interested in knowing who they were and the "Earth" -not land, this time- ironically laughs at her "passionate, proud boys" (line 13) as they are all dead now and have nothing to possess, yet they are still a part of the "Mother Earth" because death as a natural process has transformed their bodies into a lump of mould and mould into tree. Eventually, "the land" which is used to serve their needs and greed, has become "their grave" and then "their home," once again to give them back life in the form human and non-human structures.

The second part of the poem includes the reply of the Earth, composed in a non-metrical form of a lyrical song entitled, EARTH-SONG where the speaker is Nature, namely Hamatreya. Despite human efforts to take hold of the land by law, passed from father to son, nature demands the land belongs to itself as "mine and yours/mine, not yours/earth endures/stars abide/ [...] I who have seen much/such have I never seen/ [...] the lawyer's deed/ran sure/in tail/ [...] here is the land/ shaggy with wood/but the heritors?/ fled like the flood's foam/ [...] they called me theirs/whoso controlled me/ yet everyone/ wished to stay/ and is gone/ how am I theirs/ if they cannot hold me/ but I hold them?"(lines 28-58). Contrary to the romantic representation of the land as a simple, fragile commodity in the first section, the earth-song part portrays nature as "wild," "shaggy," "old" underlining the idea of an active entity, a flux of energy inherited in universe.

The last part of the poem, told in a rhyming quatrain, emphasizes the transformation of the persona has gone through from the beginning until the end as for the human being now is able to understand nature therefore he can appreciate the meaning and necessity of the Earth as he says, "when I heard the Earth-song/ I was no longer brave/ My advance cooled/ Like lust in the chill of the grave" (lines 60-64). Human ambition can be erased on the condition that one knows how to read and respect nature. This brings into mind the famous quotation of Emerson as he states in "I Become a Transparent Eye-Ball" published in Nature essays: "In the woods too, a man casts off his years, as the snake his slough/ [...] I become a transparent eye-ball. I am nothing; I see all/ the currents of the Universal Being circulate through me/ I am part or particle of god/In the woods, we return to reason and faith/ There I feel that nothing can befall me in life,/ no disgrace, no calamity which nature cannot repair/ All mean egotism vanishes" (Emerson, 1844a: np).

In the frame of Zapf's triadic model, what constructs a "culture-critical meta-discourse in Emerson's poem "Hamatreya" is the representation of American Manifest Destiny foregrounded in Puritan Work Ethic that highlights American Expansionism, Imperialism and the colonial ideology of the early settlers among whom Emerson's heritage is embedded with -not to forget the poetic heritage he takes after Edward Taylor and Anne Bradstreet. Manifest Destiny, "coined in 1845 as the belief in America's destiny to expand its dominion and spread democracy and capitalism across the entire North American continent" (History, 2019: np) has been approached through critical lenses especially by the Transcendentalists such as Emerson and Thoreau. Paradoxically inheriting his grandfathers' ideological destiny as well as the poetic Puritan legacy, Emerson through his unorthodox practices, nevertheless persists in confronting the socalled dominant ideology which dictates the land to be consumed, exploited and tamed for the benefit of man. The representation of the founding fathers of Concord -ironically reminding Emerson's endeavor in constructing unconventional Brook Farm experience in Boston, Concord- as "boastful, passionate boys full of greed" who like to define themselves through their material relationship with nature is ironically undermined by the persona as he transforms from a simple human being to a spiritual nature-lover with growing eco-consciousness through the end. The subjection of the land is clearly expressed not only in Emerson's word choice (defining nature as fragile, sweet, obedient, graceful, pure, etc.) and syntax (relocating nature in passive voice and man in active) but also in verse type as he prefers using blank verse in the first part for the treatment of ruling ideology and its hegemonic practices in a more traditional, fixed form of poetic structure contrary to the free-verse song in the next part where nature speaks unrhymed and uneven, followed with a modern stanzaic quatrain in the final part where the transformed persona muses on harmony and balance.

The meta-discourses of Western Imperialism and Industrialism operating in American culture are criticized through the warning the poem underlines: Conformist pressures will bring death, decay and alienation as long as human discourse relies on "will 
to power4." In a parallel way, H. D. Thoreau in his famous nature-writing Walden considers factors that facilitate life as obstacles to self-development and socio-cultural progress. To him, materiality consumes nations; civilization has a progressive effect on our lives but not upon our characters (qtd in Ozdag, 2005: 60). In other words, the human being is already consumed (by anthropocentric deeds and egocentric greed) whilst he thinks he is consuming the land. Thus, the transience of humanity in front of nature's permanence is an example for the Heideggerian representation of absence-in-presence ${ }^{5}$. In a culturecritical meta-discourse, the first part of the poem argues that civilization works against nature prophesying war.

Secondly, what functions in Emerson's poem on an imaginative counter-discourse is the part where the Earth speaks. Contrary to anthropocentric view which centers on the subjection of the land, nature in the poem conveys an ecocentric approach that privileges nonhuman over the human. In the second part, "earth" rather than "land" is described as "wild," "shaggy" and "old" undoing the fragility pre-established by man whose actions to possess and cultivate the land have been void. Nature, once silenced and marginalized, now acts in the subject position, subverting the contents of civilization such as Industrialism, colonization, agriculture, technology, law, etc. next to diminishing the meta-discourse of Western thinking as the second part relies on the Eastern source of Hinduism via the agency of Hamatreya, who advices man to listen. The unofficial and non-hierarchical speech that flows in a fragmented form of energy transfer from the persona to the reader brings Bakhtinian "polyphonic discourse ${ }^{6 \prime}$ into mind as the second part prevails more like the Dionysian whereas the first part acts like the Apollonian. The concept of Apollonian and Dionysian is further expressed by Civelekoglu in her article, "Ancient Greek Tragedy and The Ecology of Culture" (2013):

Nietzsche, in The Birth of Tragedy, takes the two main deities of ancient Greece, Apollo and Dionysus, so as to explicate the devices and the development of ancient Greek tragedy. The effect of catharsis, in the Nietzschean sense, is achieved through the Dionysian constituent [...] To put it differently, Nietzsche's foremost motivation is to expound the dead end of culture, which 4 . Nietzsche's concept of "will to power" (1883) can be defined as the driving motif of power working in all human beings.

5 In the article "The Question Concerning Technology," (1953) Heidegger talks about the modern "technological reasoning/unframing" which treats nature as a standing reserve whereas "poetic presencing" considers nature in subject positions (qtd in Rigby, 2004: 428-430)

6 M. Bakhtin's concepts of "dialogism", "heteroglossia", "polyphony" (1929) emphasize the multiplicity of voices and perspectives within a text. remains behind the Apollonian veil which tends to hide the Dionysian barbaric enthusiasm [...] (2013: 340, 341)

In addition to the polyphonic structure of the poem that stresses on nature, change and flux of energy both in text and universe, the second part of the poem challenges the subjection of nature underlined in the first part which is told from an anthropocentric view in a fixed poetic form.

The last part of the poem is a four-lined quatrain, simple in form and straightforward in idea. The persona again shifts from nature in the previous part to the human being in the final section, however the persona has experienced a metamorphosis after he has listened to Earth-song. As a transcendentalist, experience lies at the heart of Emersonian philosophy because self-quest is a way for man to learn himself as much as learning the universe. Therefore, the poem remarks on the significance of "individual being" which is related to the universal Over-soul by means of observing the operations in nature. It is for that reason Emerson's poem functions as an example for a "reintegrative inter-discourse" calling for balance, harmony and interrelatedness in between human and non-human natures. However, this can happen on the condition that man learns how to understand and appreciate nature. True reading of nature may save the universe as much as the idea of "poetry as dwelling" saves the earth. Emerson's poem "Hamatreya" resonates the seminal ideas of early nature-writers like that of John Muir and Edward Abbey as the former has portrayed nature in passionate and enthusiastic ways stressing on natural serenity and beauty whereas the latter stressed radically on severe precautions to be taken in to protect nature and advised people to be eco-conscious in order to stop techno-industrial state interferences within the environment (qtd in Ozdag, 70-75). In that sense, Emerson's poem is argued to be a literary example of sustainability showing us the transformative relation between nature and culture, human and non-human, past and present, material and spiritual, the East and the West.

\section{WALT WHITMAN'S “THE SPLENDID, SILENT SUN" (1865)}

Walt Whitman (1819-1892) as a devoted follower of Emerson both in idea and practice, realized Emersonian legacy in such a successful way that he is labeled as the poet of a nation. Whitman has discussed the idea

\footnotetext{
7 The ecocritical writer Jonathan Bate in discussing the idea of Heidegger's "ecopoiesis/ poetry as dwelling," claims that poetry is the only medium by which we make a dwelling in nature that equals to saving the earth (qtd in Rigby, 2004: 428-430).
} 
of the poet and purpose of poetry in a parallel vein with Emerson in his Preface to Leaves of Grass (1855). To begin with, Emerson's notion of the ideal poet as representative man flourishes in Whitman's bardic cry through his sincere, equal, intimate treatment of the reader as he notices in the first line of "Song of Myself," he celebrates himself and sings himself and what he assumes, will be assumed by the reader, too. Secondly, Emerson's idea of man's divinity is revealed in Whitman's interpretation of the "organic unity" that functions in-between man-nature-god. Thirdly, Emerson's notion of the poet as democrat is interwoven with Whitman's interest in Jacksonian Democracy which is fulfilled through his faith in the brotherhood of man, universalism, egalitarianism and simplicity. Fourthly, Emerson's reliance on the Eastern sources appears in Whitman's celebration of the union of opposites as cosmic oneness. Other than that, Emerson's strong warning against the ascendancy of the past is displayed in Whitman's grip in the present and questioning history. Moreover, Emerson's nonregulatory treatment of the subject matter is visible in Whitman's choice of subject regardless of racial, sexual, cultural restrictions. Next to that, Emerson's definition of poetry "not as meters, but a meter-making argument" is exemplified in the prosaic, epic poetry of Whitman. And finally, Emerson's idea that "America is the stuff of poetry" is described in the last part of his Preface to Leaves of Grass (1855):

The poems distilled from other poems will probably pass away. The coward will surely pass away. The expectation of the vital and great can only be satisfied by the demeanor of the vital and great... It rejects none, it permits all. An individual is as superb as a nation when he has the qualities which make a superb nation. ... If one is true, the other is true. The proof of a poet is that his country absorbs him as affectionately as he has absorbed it (1855: 26).

Emersonian legacy has been a striking point of reference in Whitman's poetry. It is through this strong Transcendentalist tendency that makes Whitman the poet laurate of America. However, Whitman is perceived to lose the optimistic and holistic tones in his late poetry and his poem "The Splendid, Silent Sun" appearing in his Drum-Taps collection of 1865, succeeds as one of those high-spirit Whitmanesque compositions yet turning its face to pessimism, slowly. The poem provides with an ecological text within culture that establishes a mutual relationship between the opposing poles in universe such as nature and culture, city and countryside, male and female, tranquility and chaos, war and peace, life and death.
The dynamic complexity of the poem corresponds with Bateson's notion of "connecting patterns" between mind and matter, human and nonhuman spheres (qtd in Zapf, 2016:35). The poem reflects Rueckert's idea of poetry as "stored energy":

This energy flows out of Whitman into the world (all the things of the world) and back into Whitman from the things of the world in one of the most marvelous ontological interchanges one can find anywhere in poetry. This ontological interchange between Whitman and the biosphere is the energy pathway that sustains life in Whitman and, so far as he is concerned, in the biosphere. There is a complete ecological vision in this poem. Whitman says that poems come out of the poets, go up into the atmosphere to create a kind of poetic atmosphere, come down upon us in the form of poetic rain, nourish us and make us creative and then are recycled. Without this poetic atmosphere and cultural cycle, he says, we would die as human beings. (Rueckert, 1978: 118)

The idea of Civil War (1861-1865) has a big impact on the poems included in his Drum-Taps collection one of which is "The Splendid, Silent Sun." The poem composed in an intense Whitmanesque fashion of free-verse, speech-based, unrhymed prosaic structure, which is divided into two sections, meditates on persona's inner conflict displayed through opposing concepts such as the rural America vs urban America. The first part stresses on the tranquil description of the countryside as the sun is shining in a splendid yet indifferent way with rays dazzling on fruits ripe and red, where the grass grows uncut over the gardens of beautiful flowers so that the persona can walk undisturbed with a sweet woman and children next to him:

GIVE me the splendid silent sun, with all his beams full-dazzling;

Give me juicy autumnal fruit, ripe and red from theorchard;

Give me a field where the unmow'd grass grows;

Give me an arbor, give me the trellis'd grape;

Give me fresh corn and wheat-give me serene-moving animals, teaching content;

Give me nights perfectly quiet, as on high plateaus west of the Mississippi, and I looking up at the stars;

Give me odorous at sunrise a garden of beautiful flowers, where I can walk undisturb'd;

Give me for marriage a sweet-breath'd woman, of whom I should never tire; 
Give me a perfect child - give me, away, aside from the noise of the world, a rural domestic life;

Give me to warble spontaneous songs, reliev'd, recluse by myself, for my own ears only;

Give me solitude—give me Nature-give me again, $O$ Nature, your primal sanities! (Whitman, 1865: Lines 1-12)

The romantic portrayal of natural landscape described through positive images such as beautiful, serene, reclusive, mild, fresh, quiet, sweet, etc are put forward in a demanding discourse by the persona as he begins each line with "Give Me" until he is overwhelmed by the rural spirit so that he switches into "Keep" in the second part where he starts talking about the urban life through words that would subvert the ones previously used: crowd, noise, interaction, energy, chaos, war, multitude, etc:

Keep your splendid silent sun;

Keep your woods, O Nature, and the quiet places by the woods;

Keep your fields of clover and timothy, and your cornfields and orchards;

Keep the blossoming buckwheat fields, where the Ninth-month bees hum;

Give me faces and streets! give me these phantoms incessant and endless along the trottoirs!

Give me interminable eyes! give me women! give me comrades and lovers by the thousand!

Let me see new ones every day! let me hold new ones by the hand every day!

Give me such shows! give me the streets of Manhattan!

Give me Broadway, with the soldiers marching-give me the sound of the trumpets and drums! (Lines 20-36)

The rejection of urban life in the first part fuses with the celebration of city life in the second, underlining diversity and dynamism operating in universe. Whitman's urban motifs resonate with rural ones as both are treated separate but equally. Through the use of binary oppositions in a destabilized way as none is privileged over the other, the poem helps construct "singularity and connectivity, similarity and difference, interrelatedness and diversity" (Zapf, 2016: 12). As the persona allows himself to be consumed by the glamour of big city, he rejects the prospects of the silent earth (Killingsworth, 2004: Chp. 5), so the poem ends with the portrayal of soldiers marching in the streets of Manhattan as city lights and sounds overlap with drum taps and Broadway music.

According to Zapf's triadic functionality of literature, the first model is "culture-critical meta-discourse" which is revealed through the concept of urbanization in the poem. The city life that keeps the persona (as much as Whitman, himself who is known as the poet of the city) alive, feeds on war, civilization, imprisonment, consumption, industrialism, etc. Imperialism and westward expansion are rooted in the ideological manifestation of American culture which is triggered by the Civil War (1861-1865). Whitman, who is severely affected by the brutality of the war as much as fascinated by it to some extent, still sticks to the ideology that produces and justifies war. His patriotism becomes clear as he resonates with human growth and progress, established by the idea of war. Likewise, in his poem "A Passage to India" (1871), Whitman is calling for progressive and clear mind, getting rid of old-fashioned ideas and conventions through American continental expansion (Denizarslanı, 2014: 220). Thus, Industrial capitalism protected via military, which is working as a coercive practice is justified in the urban consciousness Whitman underlines in the poem.

On an imaginative counter-discourse model of functionality, nature exists as an opposite force in the poem. Decorated with words that underline its meek, tranquil, reclusive and spontaneous structure, the countryside works to establish a transcendental reconciliation which is necessary for individual consciousness and universal harmony. Nature prevails in a splendid yet silent way, co-operating with all other natural forms, including man who finds shelter in the bosom of Earth. The cycle in nature provides (or rather gives) with home, food, love, peace and "primal sanity" (line 11), distanced from artificiality. Nature speaks a simple, universal language justifying its omniscience and omnipotence. It is the place where "all mean egotism vanishes" (Emerson, 1844a: np) and "spiritual awakening" is made possible (Thoreau, 1854:np). Contrary to coercive practices of Industrial capitalism embedded within American ideology of civilization, nature works through unregulated, rural practices endowed with simplicity and harmony as the poem underlines. As a model for counterdiscourse, Whitman's portrayal of nature ties human to his most cherished sentiments, lost by urbanization and civilization. Therefore, persona's yearning for rural life might be an example for the second mode of functionality according to Zapf's theory. 
Lastly, as a reintegrative inter-discourse functionality model, Whitman's poem is argued to represent a dynamic interaction between the opposing forces such as nature and culture, rural and urban, individual and society, chaos and tranquility, war and peace, the North and the South. Yet, in a paradoxical way the city life that tires him also enriches his soul. The war that kills so many, also introduces a new life. The urban chaos that suffocates him, also launches new possibilities in front him. The city of Manhattan, with its turmoil, chaos and energy prevails as a polyphonic place whereas the countryside of Mississippi with its idyllist spirit exists in serenity. The "biophobic discourse" of war in the second part of the poem is contrasted with the "biophilic discourse" of nature in the first part. Thus, what makes the poem striking in terms of Zapf's triadic model is that, both sides need one another to sustain life forms for the human and non-human. Rather than privileging one form over the other, what matters in Whitman's poem is the interrelatedness operating between two realms. In that sense, the text might be placed in a "choreography of becoming" (Coole and Frost qtd in Iovino and Oppermann, 2012: 79).

\section{CONCLUSION}

According to Zapf, "literature can itself be described as the symbolic medium of interconnectedness operating between nature and culture, human and non-human universes;" thus, literary works can be examined as the dynamic interrelation of three major discursive functions as of a culture-critical meta-discourse, an imaginative counter-discourse, and a reintegrative inter-discourse (2016:27). In the first model, the artistic work is analyzed to reveal the workings of an oppressive ideological structure and dogmatic values of the society whereas the second one points out the representations of otherness and marginalization within a text and finally last one tries to exemplify the co-evolution of both models in searching for the "transformative role of literature" within "ecosemiotic" discourse. In that sense, this article intends to find out how the poetic examples of Emerson and Whitman fit into the triadic model of cultural ecology. The argument proceeds through the illustration of Zapf's triadic model in Emerson's "Hamatreya," and Whitman's "The Splendid, Silent Sun" as both poems reveal the workings of ruling ideology in American culture in the nineteenth century at the same time subverting the so-called meta-discourses of Industrial capitalism and Manifest Destiny. In the frame of Zapf's triadic model, what constructs a culture-critical meta-discourse in Emerson's poem "Hamatreya" is the representation of American Manifest Destiny foregrounded in Puritan Work Ethic that highlights American Expansionism, Imperialism and the colonial ideology. On an imaginative counter-discoursive level, the second part where the Earth speaks is important to notice. Contrary to anthropocentric view which centers on the subjection of the land, nature in the poem conveys an ecocentric approach that privileges non-human over the human. As the last section of the poem implies, the work functions as an example for a "reintegrative inter-discourse" calling for balance, harmony and interrelatedness in between human and non-human natures.

In terms of Whitman's poem, the first model is culturecritical meta-discourse which is revealed through the concept of urbanization in the poem. Industrial capitalism protected via military, which is working as a coercive practice is justified in the urban consciousness Whitman underlines in the poem. On an imaginative counter-discourse model of functionality, nature exists as an opposite force in the poem. It works through unregulated, rural practices endowed with simplicity and harmony in juxtaposition with urban motifs. Lastly, as a reintegrative inter-discourse functionality model, Whitman's poem is argued to represent a dynamic interaction between the opposing forces such as nature and culture, rural and urban, individual and society, chaos and tranquility, war and peace, the North and the South. Allowing space for Nature to speak up for itself, both texts offer a critique for the nineteenth century understanding of civilization. In that sense, this study has described the transformative role of literature within a cultural system.

\section{REFERENCES}

- BATE, J. (2000). The Song of the Earth, Cambridge. Mass., Harvard University Press.

- BUELL, L., HEISE U., K., \& THORNBER, K. (2011). Introduction: Literature and Environment. The Annual Review of Environment and Resources, No 36. 417-440, Literature and Environment | Annual Review of Environment and Resources (annualreviews. org) [Accessed Date: 02.02.2021].

- CiVELEKOĞLU, F. (2013). Ancient Greek Tragedy and the Ecology of Culture. JASSS. 6(6), https:// jasstudies.com/DergiTamDetay.aspx?ID=1776 [Accessed Date: 10.12.2020].

- DENIZZARSLANI, Y. (2014). A Contemporary Review on Sense of Place and Border in the Nineteenth Century Narratives of American Expansionism, IJLA, 2(1). 
- DUNNING, K. (2013). From Environmental Poetry to Eco-poetry. www. from Environmental Poetry to Ecopoetry - PDF Free Download (docplayer.net) [Accessed Date: 10.01.2021].

- EMERSON, R. W. (1844a). The Nature, Essays: Chp I. Emerson - Nature--Web Text (Vcu.Edu) [Accessed Date: 14.12.2020].

- EMERSON, R. W. (1844b) The Poet, Essays: Second Series. emerson - Essays - The Poet (vcu.edu) [Accessed Date: 10.12.2020].

- EMERSON, R. W. (1846). "Hamatreya" Hamatreya by Ralph Waldo Emerson I Poetry Foundation [Accessed Date: 10.12.2020].

- GLOTFELTY, C. \& Fromm, E. eds., (1996). The Ecocriticism Reader: Landmarks in Literary Ecology. Athens: University of Georgia Press.

- IOVINO, S. \& OPPERMANN, S. (2012). Material Ecocriticism: Materiality, Agency, and Models of Narrativity. Ecozon.3(1). [Accessed Date: 10.12.2020].

- KILLINGSWORTH, M. J. (2004). Walt Whitman and the Earth: A Study in Ecopoetics. Walt Whitman and the Earth: A Study in Ecopoetics (Criticism) - The Walt Whitman Archive [Accessed Date: 10.12.2020].

- "manifest destiny" (2019). HISTORY. Manifest Destiny - Definition, Facts \& Significance - HISTORY [Accessed Date: 10.12.2020].

- NIETZCHE, F. (1883). The Will to Power, The Project Gutenberg eBook of The Will to Power, Book I and II, by Friedrich Nietzsche. [Accessed Date: 10.12.2020].

- OZDAĞ, U. (2005). Edebiyat ve Toprak Etiği: Amerikan Doğa Yazınında Leopold'cu Düşünce, Ankara: Ürün Yayınları, http://yunus.hacettepe.edu.tr/ ozdag/ Edebiyat ve Toprak Etigi Ufuk Ozdag.pdf [Accessed Date: 10.12.2020].

- RIGBY, K. (2004). Earth, World, Text: On the (Im) possibility of Ecopoiesis. JSTOR, www.JSTOR.com [Accessed Date: 12.06.2020].

- ROBINSON, A. (2011). In Theory Bakhtin: Dialogism, Polyphony and Heteroglossia. CEASEFIRE. In Theory Bakhtin: Dialogism, Polyphony and Heteroglossia I Ceasefire Magazine [Accessed Date: 12.06.2020].

- RUECKERT, W. (1978). Literature and Ecology: AN EXPERIMENT IN ECOCRITICISM, William Rueckert's Literature and Ecology: An Experiment in Ecocriticism | Environment \& Society Portal (environmentandsociety.org) [Accessed Date:20.03.2021].

- SCIGAJ, L. M. (1996). Contemporary Ecological and Environmental Poetry, ISLE. Vol 3. No 2. www.jstor. org [Accessed Date: 12.06.2020].
- SHUCARD, A. (1988). American Poetry, Boston: Twayne Publishers.

- STRANG, E. (2013). Habitude: Ecology of Poetry as (Im) possible Interconnection. (PDF) Habitude: Ecological Poetry As (Im)Possible (Inter)Connection I Em Strang - Academia.edu [Accessed Date: 12.03.2021].

- THOREAU, H., D. (1854). Walden: Where I Lived and What I Lived For. 2015, The Project Gutenberg eBook of Walden, by Henry David Thoreau [Accessed Date: 12.03.2021].

- WHITMAN, W., (1865), "Give Me the Splendid, Silent Sun," 130. Give me the Splendid, Silent Sun. Whitman, Walt. 1900. Leaves of Grass (bartleby.com) [Accessed Date:21.01.2021].

- ZAPF, H. (2016). Literature as Cultural Ecology, Bloomsbury Academic 2016,. Bloomsbury Collections - Literature as Cultural Ecology - Sustainable Texts [Accessed March 2021].

\section{ENDNOTES}

- IOVINO, S. \& OPPERMANN, S., (2012). Material Ecocriticism: Materiality, Agency, and Models of Narrativity, Ecozon, Vol 3 No 1, [Accessed Date: 12.2020].

- RUECKERT, W., (1978), Literature and Ecology: AN EXPERIMENT IN ECOCRITICISM William Rueckert's Literature and Ecology: An Experiment in Ecocriticism । Environment \& Society Portal (environmentandsociety.org) [Accessed Date: 03.2021].

- SHUCARD, A. (1988). American Poetry, Boston: Twayne Publishers.

- NIETZCHE, F. (1883). The Will to Power. The Project Gutenberg eBook of The Will to Power, Book I and II, by Friedrich Nietzsche. [Accessed Date: 12.2020].

- RIGBY, K. (2004). Earth, World, Text: On the (Im) possibility of Ecopoiesis. JSTOR, www.JSTOR.com [Accessed Date: 06.2020].

- ROBINSON, A. (2011). In Theory Bakhtin: Dialogism, Polyphony and Heteroglossia. CEASEFIRE. In Theory Bakhtin: Dialogism, Polyphony and Heteroglossia I Ceasefire Magazine [Accessed Date: 06.2020].

- RIGBY, K., (2004). Earth, World, Text: On the (Im) possibility of Ecopoiesis. JSTOR, www.JSTOR.com [Accessed Date: 06.2020]. 